\title{
EENIGE, IN HET HANDWOORDENBOEK VAN ROORDA, NOG NIET OPGENOMEN JAVAANSCHE WOORDEN.
}

Prof. Meinsma heeft de goedheid gehad mijne aandacht te vestigen op sommige in Roorda's Jav. Ned. Handwoordenboek nog niet opgenomen woorden, voorkomende in het in 1876 te Batavia verschenen Jav. werkje getiteld: "Tjariosing negari Padang, door Radèn Ariå Darmå Bråtå."

Daarbij gaf ZHGel. mij in overweging die woorden en enkele uitdrukkingen, zooveel mogelijk te verklaren en ze in de Bijdragen van het Koninklijk Instituut te publiceeren. Zonder daarom te durven beweren dat de door mij geleverde verklaring voldoende zij, wil ik daaraan gaarne gevolg geven, wèl overtuigd, dat elke poging, hoe gebrekkig ook, om de kennis van de Jav. taal te vermeerderen, niet geheel nutteloos is. Het spreekt van zelf dat deze mijne bijdrage geenszins aanspraak maakt op wetenschappelijke waarde; ik heb eenvoudig getracht terug te geven wat de Javaan over 't algemeen onder die woorden verstaat en wat hij met die uitdrukkingen zeggen wil. Voor het gemak van den belangstellenden lezer kan deze bijdrage beschouwd worden als een vervolg op het door voornoemden geleerde verleden jaar in dit tijdschrift 4e volgr. 3e dl. blz. 241 geplaatste "Eenige bijvoegsels bij het Jav. Ned. Hdw. van 'T. Roorda." Hier en daar echter waar het mij wenschelijk toescheen, was ik zoo vrij in de uitlegging eenigszins uitvoeriger te zijn. Ook heb ik voor enkele m. i. nog niet voldoend verklaarde woorden, die ik in Humme's A biåså en elders aantrof, hier een plaatsje ingeruimd. Omtrent sommige te Padang gebruike- 
lijke woorden en uitdrukkingen in het eerstgenoemde werkje voorkomende, die mij twijfelachtig voorkwamen, heb ik van den schrijver zelven inlichtingen ontvangen.

Ten slotte veroorloof ik mij den beoefenaars van het Javaansch in bedenking te geven, de Jav. woorden, waarvan de beteekenis hun $\min$ of meer duister voorkomt, van tijd tot tijd, met of zonder uitlegging, maar liefst met opgave van herkomst en van den zin waarin ze voorkomen, in het licht te geven zooals b. v. Dr. N. van der Tuuk ten aanzien van oud-Javaansche woorden in het Tijdschr. voor Ind. taal-, land- en volkenkunde dl. XXV gedaan heeft. Zoo doende zal men, dunkt mij, voor anderen en voor zich zelven een nuttig werk verrichten.
Delft, September 1880.
IsMANGOON D. W. 


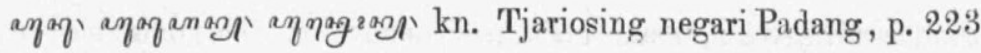
r. 10 ; besproeien, besproeiing; water dat naar de sawah wordt geleid, z. v. a. 2inย彡 ofa waarmede dit eenigszins in verband schijnt te staan.

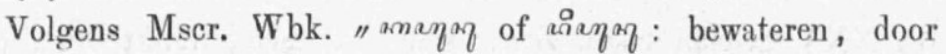
inleiding van water langs greppels. "

aүminy аұming kn. Tj. n. Pad. p. 319 r. 6 v. o. kleine

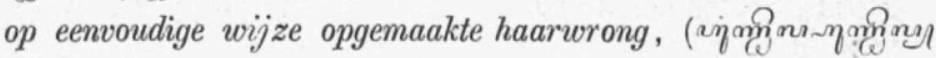
groote haarwrong, al naar gelang de persoon die ze draagt weinig of veel haar heeft). Het verschil dezer haarwrong met de kondé bestaat voornamelijk hierin, dat de laatste minder eenvoudig is, door dat het gedraaide haar door elkaar heen gestoken en als het ware geknoopt wordt, hetgeen met de eerste niet het geval is.

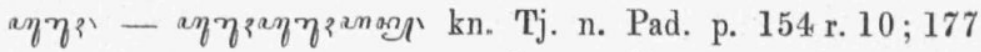

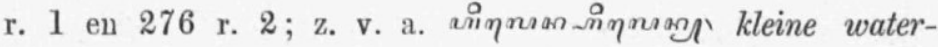
leiding, speciaal gezegd van beekjes die van de bergen afstroomen en uit een bron of meertje ontspringen.

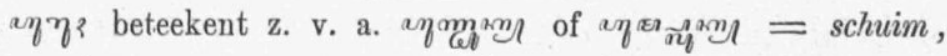

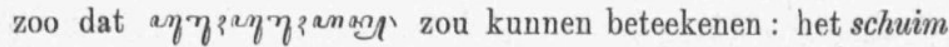
of schuimend water van het meer of van de bron.

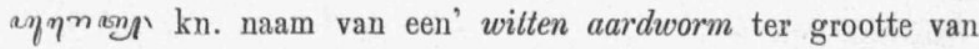
een duim. Zie an๕л

аๆ 돈 kn. A biåså p. 35 r. 8 v. o. letterlijk: diepe, zware of

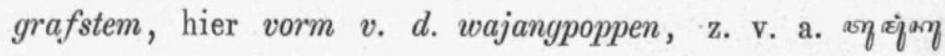
ng ny stelling van vroolijk], zoo als die van Ardjoenå, Yoeḍis-

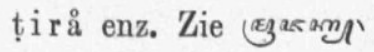

ayzma - ancygmi kn. Tj. n. Pad. p. 258 r. 9 ; het dwar- 
relen van iets = aqram zin van: de geur die al dwarrelende gestadig in den neus dringt.

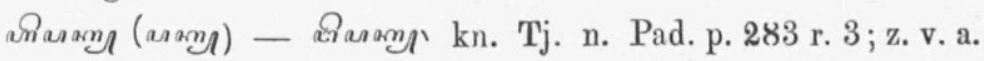

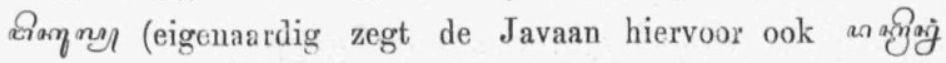
in den zin van ik ben de baas), iemand met aanmatiging, minachting of vernedering behandelen. asхи beteekent oorspronkelijk het klanknabootsend geluid van slaan op het hoofd

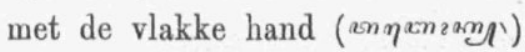

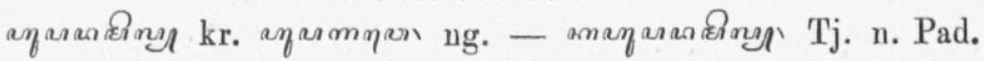
p. 291 r. 8 v. o. kwaad doen; kwaad gedaan worden, ge-

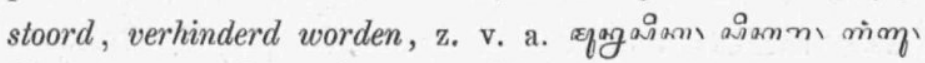

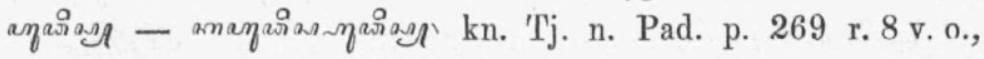
sterk op iets aandringen; sterk op aangedrongen worden; met den kop of den snuit (hier van het kalf) woelen tusschen de achterpooten (bij de lies) van den buffel, z. v. a. भิarm? b. v. भिR

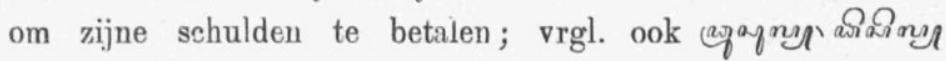
Bijdr. K. I. 1879 , 3e dl. p. 258. Volgens Mscr. Wbk. be-

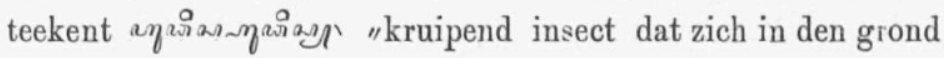
ophoudt. "

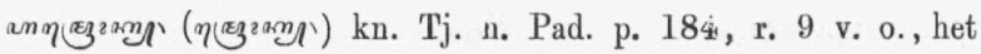
in menigte ergens verspreid liggen, zitten ook staan van vele meest kleine voorwerpen of diertjes, zoo als: vuurvliegen q̣am raj des nachts op de sawah of aan den oever der rivier; van afgevallen bloemen z. a. tandjoeng, kemoening of melati bloemen enz.; van in bloei staande plantjes, z. a. madeliefjes op 't veld, vooral van schitterende voorwerpen b. v. sterren, zoodat men ook kau zeggen: nià่an ณิnay

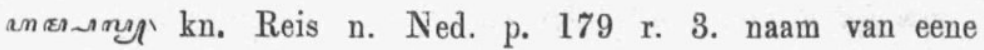
grïze tor (ter grootte van een ợinal) die uit het masker

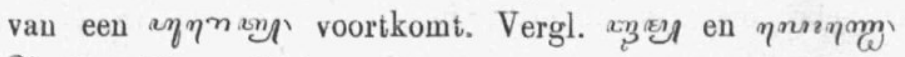
an丝 Kn. Tj. n. Pad. p. 196, r. 9; zacht, gemakkelijk, aangenaam, gelijkmatig, glijdend of rollend van voer- en vaar4e Volgr. IV. 
tuigen enz. Zoo ook het gevoel van sluimeren en in slaap geraken.

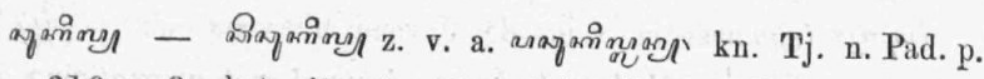
216 r. 8 , het uitpeuteren yan iets (den grond) met een klein

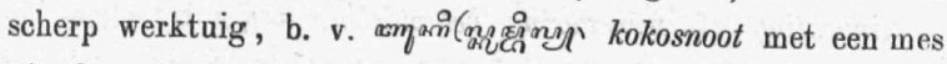
uit den dop peuteren. Hier heeft het woord de speciale beteekenis van ancnagl 't ontginnen, het stichten.

Volgens Mscr. Wbk. beteekent againngl "de afstammeling van iemand die een stuk grond ontgonnen heeft of de plaats waar iemands voorvaderen geboren zijn, b. v. aiama qaว

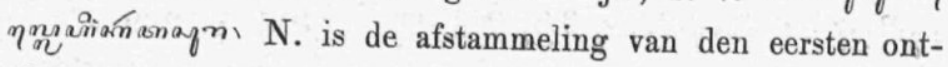
ginner van Karta Soera."

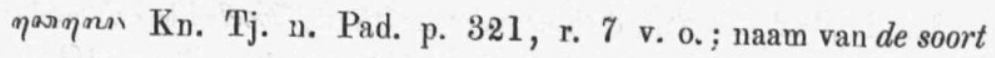
of 't patroon van rynoxn! maar meest gekleurd en met smaller streepjes. Volgens Mscr. Wbk, " een soort van Europ. geruit goed, "

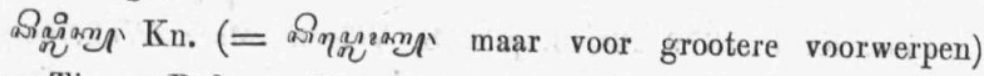
Tj. n. Pad. p. 157 , r. 5,4 en 1 v. o. I. klein voorwerp op een grooter vastgehecht of geplakt. Hier beteekent aิaim eene versiering van goud, zilver of diamant aan een aysiai any d. i. oorkrab vervaardigd van buffelhoorn, ook ay aำi geheeten, in tegenstelling van aqRienays

II. de stengel of steel van een bamboeblad, ook lootjes of uitspruitsels die aan de geledingen der bamboes uitschieten, wat bij boomen erqargal is.

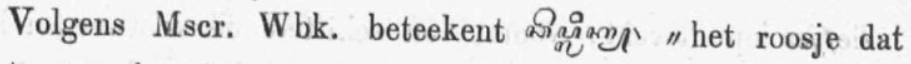
met een schroefje aan de soewĕng zit."

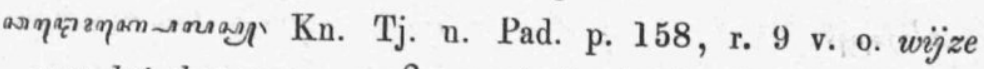
van het dragen van on aip zoodanig dat de uiteinden daarvan bij de heup zijn sannengevoegd en vastgemaakt zonder dat ze eerst om het onderlijf heen is gewikkeld, zoodat dit laatste zichtbaar wordt, zoodra de onaipi door den wind in beweging raakte. Het woord is samengesteld uit ar 


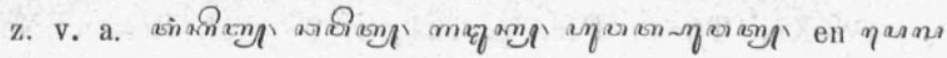
趷 een van kědělé en geraspte kokosnoot bereide toespijs, gewoonlijk bij het koken gewikkeld ajorgasl in een stuk pisangblad, met een kruisband - mede van pisangblad -

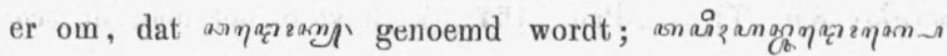
nıas beteekent: het kleed aan hebben, als het ware op de wijze van den kruisband van de qasnras

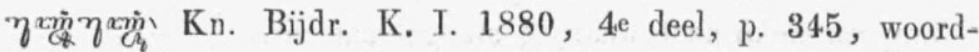

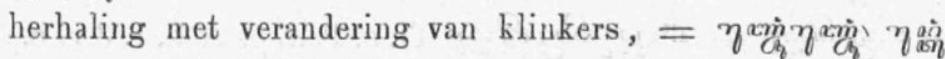
ךoì onafscheidelijk bij elkaar; eigenlijk : dicht achter elkaar

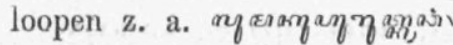

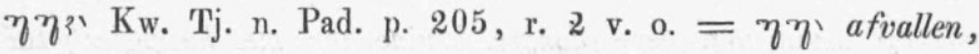

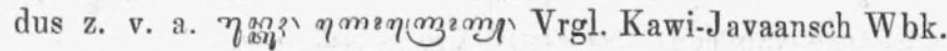
van Winter, uitgegeven door van der Tuuk.

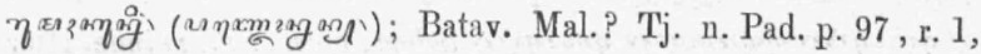
bordeel, of verblïf der danseressen, (ronggèng) z. a. het

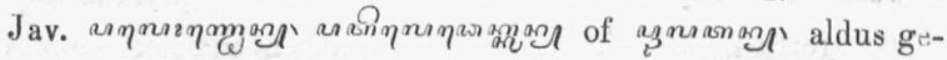
naamd naar het gebruik zoo wel te Batavia als te Padang, alwaar de bamboe- of houten wanden der huizen van dergelijke vrouwen geel geverfd zijn, althans plachten te zijn.

aлๆхmªga Kediri en Soerabaja, verkorting van asanqaкаagal grond-

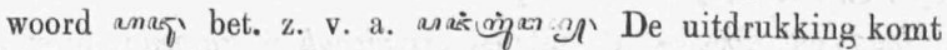

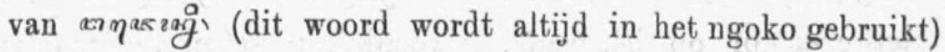
d. i. het verschijnen van den danser op het tooneel bij de danseres om met deze te tandakken. ํำin 1.

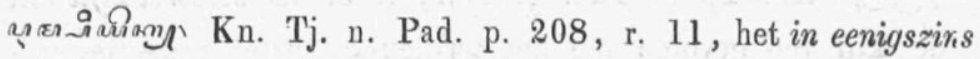
gebogen houding langzaam gaan vau oude of ziekelijke menschen.

1 Dit woord bet. niet alleen tandakken met dansmeiden op straat bij nacht, zoo als dit in het $\mathrm{Hd}$. Wbk. opgegeven is, maar ook in de pendå pa en bij

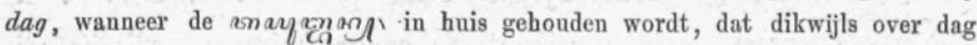
plaats heeft. 


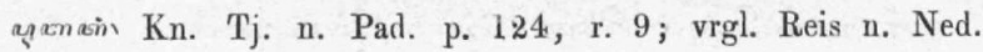

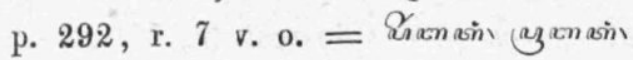

anqú, Kn. Tj. n. Pad. 157 , r. 9 v. o. het door de schutblaadjes aan het einde $v$. $d$. kokosnootsteel gevormde napje (dien naam geeft men er ten minste bij de eikels aan), waar in de noot bevestigd is, hetwelk den vorm heeft van een bekken. Volgens Mscr. Wbk. " een bekkenaardig bekleedsel van een kokosnoot waar de stengel aan zit."

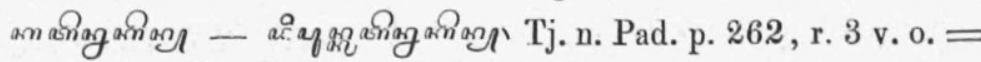

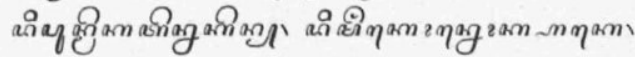

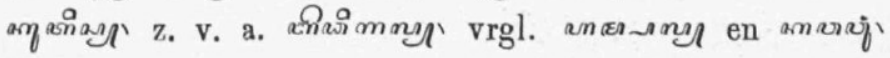
anarif naam van eene donker bruine tor met hoorntjes, ter

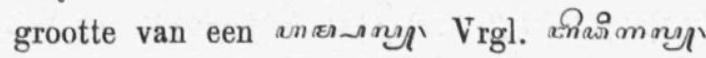
ๆamiquir Kn. Tj. n. Pad. p. 121, r. 8 en 9 v. o.; z. v. a.

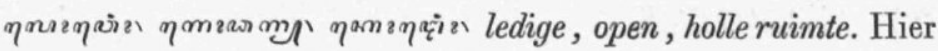
wordt bedoeld eene soort ronde, van binnen holle, mandjes, van rotting gevlochten, welke, gehangen aan een seinpaal, tot signaal dienen van aankomende schepen. Zie «๊

Volgens Mscr. Wbk. " eene opening door en door, een

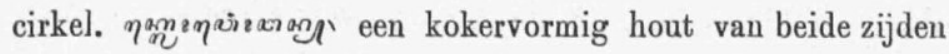
open. "

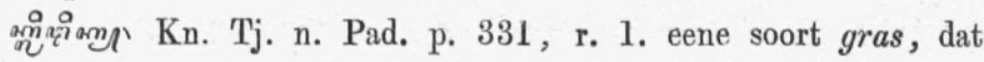
lang en dik is, er vitziet als glagah of rajoeng en in de bosschen of op het veld, gewoonlijk tusschen die planten,

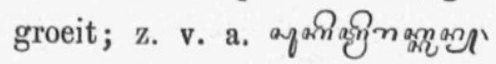

апүษзал Kn. Tj. n. Pad. p, 192, r. 5. het bemorst zïn van de kin ten gevolge van het $\mathrm{kwijlen}$ bij betelkauwende per-

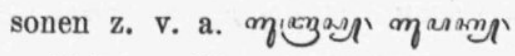

Volgens Mscr. Wbk. " bevuild, smerig (van knevels of baard, wanneer er van hetgeen men eet of drinkt wat blijft hangen). "

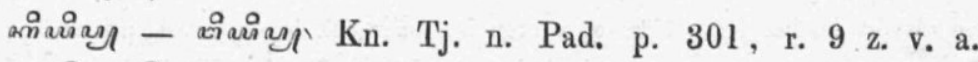

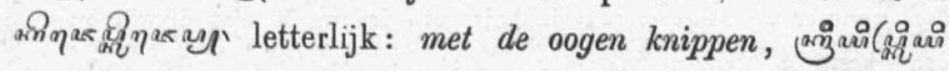


ay wordt gezegd van de oogen van iemand die, uit den slaap ontwakende, naar het licht ziet. Fig. beteekent xiaingy niet naar rede willen hooren, om niets geven, z. v. a. qan nๆखुचख्या

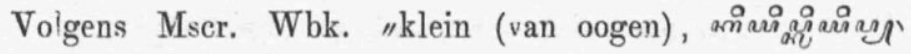
dikwijls knipoogen van iemand die kleine oogen heeft."

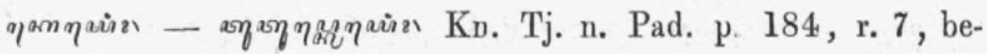
naming van rechtopgaande zïgevels van een ұапгвцамвgewoonlijk van gevlochten bamboe $\eta^{2}$ anis vervaardigd. Zie

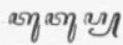

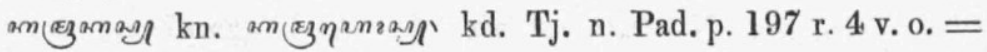

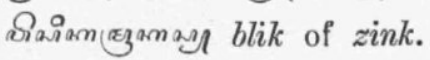

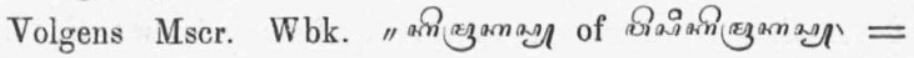
blik."

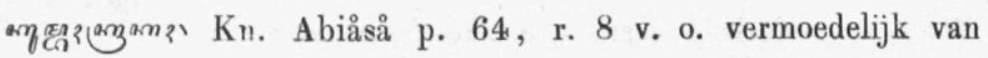

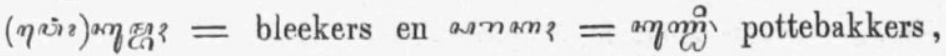
lieden die oudtiijds niet als getuigen mochten optreden, omdat zij beschouwd werden te behooren tot de gemeene kaste,

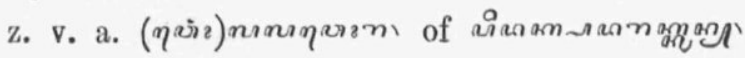

an)

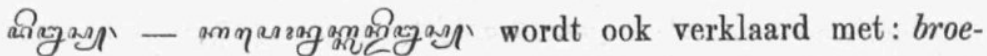
ders kinderen (nl. broeders van de zelfde " vader en moeder"), eigen neven in de mannelijke linie.

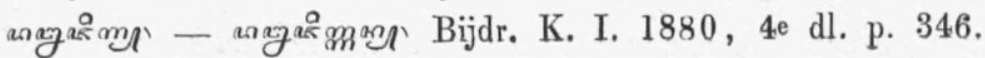

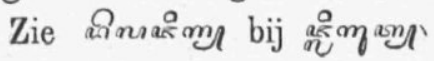

ans

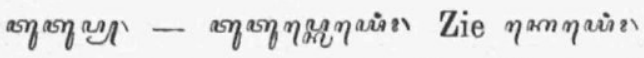

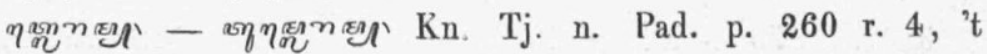
schitteren, blinken; hier het geschitter v. h. lemmer der sabels; z. v. a. onqninas

Dit laatste woord beteekent volgens Mscr. Wbk. "gefikker, flikkering, ook van blanke wapens, spiegel of water."

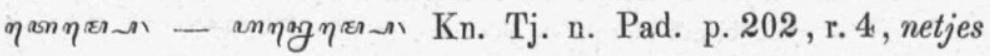




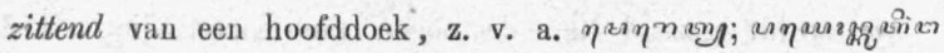

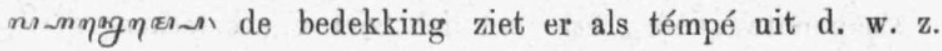

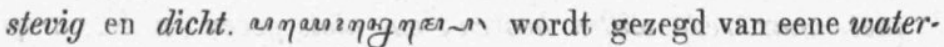
dichte bedekking, (eene nieuwe atapbedekking, waarvan de atappuntjes nog niet vermolmd of afgestompt zijn, is ge woonlijk een beetje lek).

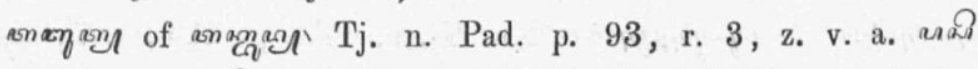

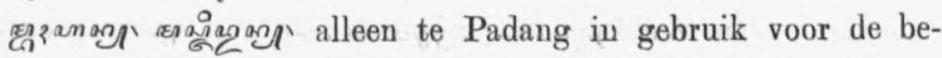
naming van een bedehuis, dat ter gelegenheid van het Hassan Hoesainfeest opgericht wordt.

Volgens prof. Niemann is taboet het Arab. تابوت = plaats waar men reliquien bewaart. Voorts wordt die naam ook gegeven aan een klein langwerpig vierkant gebouw, dat bij het Hassan Hoesainfeest het praalgraf moet verbeelden, dat op de vlakte van Kerbela over de overblyfselen van Hoesain is opgericht. Bij genoemd feest plaatst men in de taboet dikwijls of veelal twee kleine graven, waarmede men die van Hassan en Hoesain wil voorstellen.

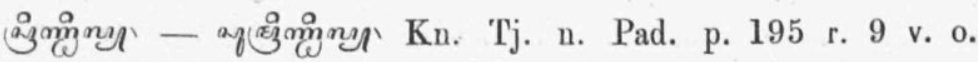
Vrgl. Palmer v. d. Broek's Kantjil, agy? IV. алал 10 en 13

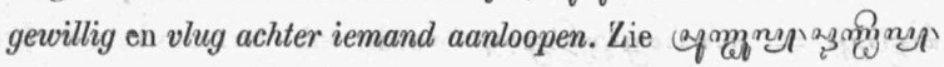
คำตัnม

asqnanny $\mathrm{Kn}$. manuscript brieven, een van 2 aan elkaar verbonden planken vervaardigd vouwlezenaartje, vooral gebruikt bij het lezen van den koran, even als de aym n ny Dit laatste wordt gewoonlijk gemaakt van een meestal niet zeer fijn afgewerkt, blok hout.

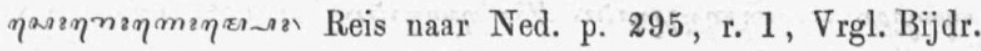
K. I. $18793^{\mathrm{e}}$ dl., p. 267; ook naam van een jongensspel, dat in Kediri gespeeld wordt, waarbij twee knapen, zich bij de handen vasthoudende, elkaar met gestrekte armen om het hardst duwen. 1. Hij wiens elleboog 't eerst buigt, is de

1 Zoo dat het reeds vroeger in 't aangehaalde tijdschrift verklaarde woord çaวha ook deze beteekenis nl. "tegen elkander duwen " heeft. 
verliezende partij en moet dan den winner een eindje op den rug dragen. $\eta m \eta \ddot{\eta^{2}}$

ดิฑ亠 Kn. Tj. n. Pad. p. 233 , r. 10; z. v. a. คํํํ diep tevens

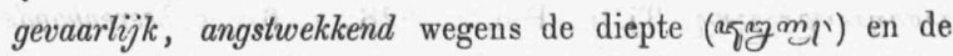
veelvuldige (monnal) gewassen, waarin gevaarlijke dieren

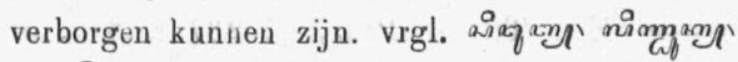

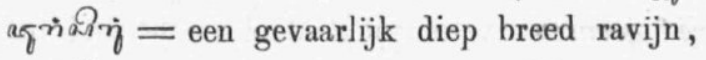
"ซึ่งiว $=$ " " smal ravijn. аралами Reis n. Ned. p. 75, r. 11 v. o. vrgl. Bijdr. K. I. 1879, 3e dl. p. 253 moet zijn ajasan

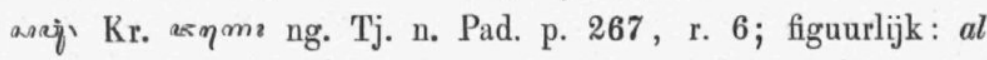
wat men laat vechten, haan, buffel, kemiri, ketjik, enz.

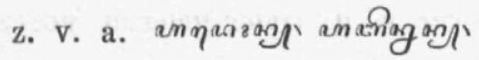

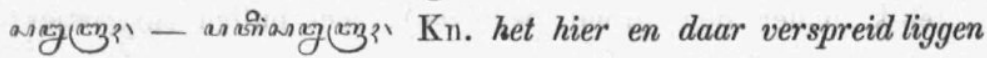
van kleedingstukken; het onderst boven van goederen.

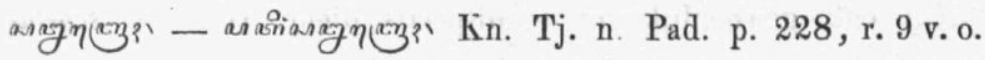

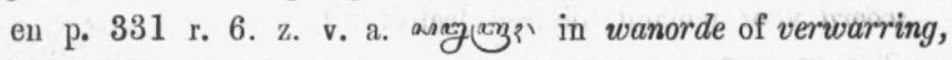

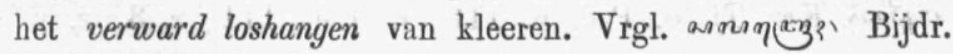
K. I. $1879,3 \mathrm{e}$ dl. p. 253.

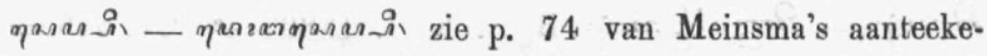
ning op de Babad Tanah Djawi; formuliergebed ๆasan 소

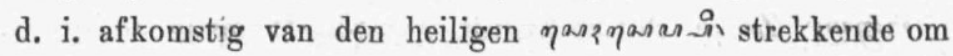
djins, satans en dergelijke van hem, die het formulier pre-

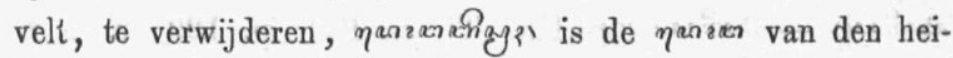

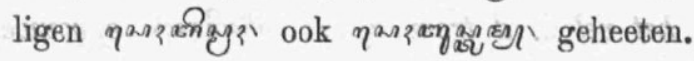

алюлиялпу Kn. Tj. n. Pad. p. 281 , r. 5 en 3 v. o. en p.

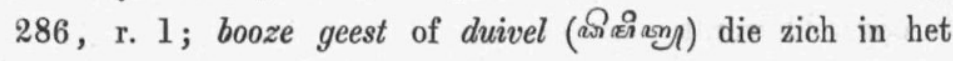
water ophoudt en zich in de gedaante van een' krokodil of

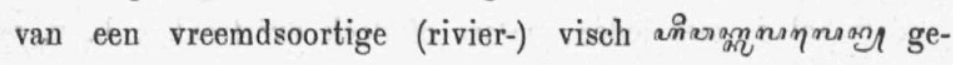
noemd, vertoont. Het bijgeloof wil, dat dergelijke visch een behaard lichaam of, juister: haar onder de ailo heeft, welk haar grof is en op aqan gelijkt. Doet de duivel zich in de gedaante van een' krokodil voor, dan is diens kop aяnฺ am ' begroeid met $\underset{n}{m} m_{3}$ Ontmoet een visscher of bader toevallig

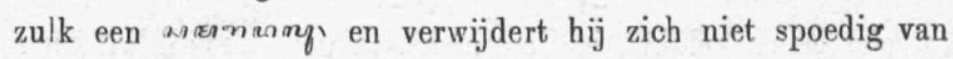


die plaats, dan loopt hij gevaar sonxi en in het verblijf des duivels verdwaald te raken. De zulke wordt вл вовпплал genoemd, d. i. door den duivel weggenomen.

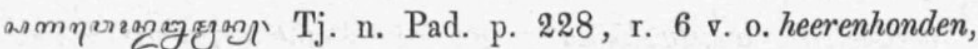

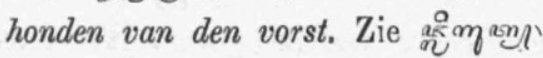

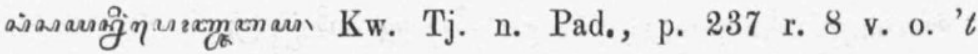
gevaar der vijf gevaren, veroorzaakt door godheden, menschen, dieren, djins en satans.

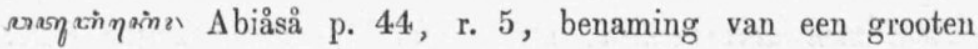
steen (gewoonlijk aan den oever v. d. rivier gelegen, gedeeltelijk onder den grond bedolven), met bulten en gaatjes, het uiterlijk hebbende van een grooten kikvorsch, waaraan hij ook gewoonlijk tot schuilplaats dient. Hier een scheldwoord voor iemand die een leelijk uiterlijk heeft.

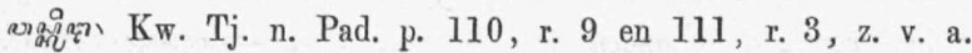
anarays 'n profetischen geest hebben, met den helm geboren zijn.

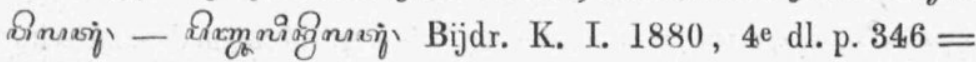

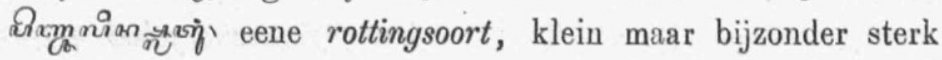

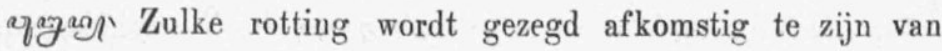
Borneo, Blitoeng en Palembang.

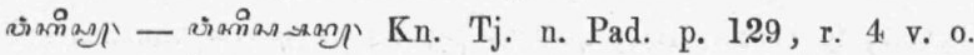
en 277 , r. 5 . het vel $v$. d.trom, z. v. a. ciming opvouwen, oprollen, omdat het (natte) leder om den rand van den trom opgerold wordt.

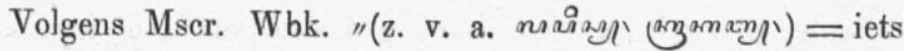
dat hol is met leder, papier of doek overtrekken b. v. van trom enz."

nx

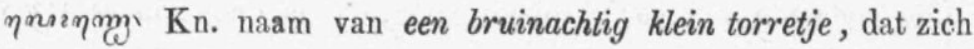

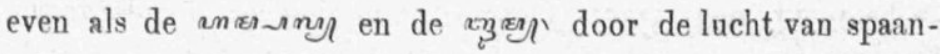
sche peper gelokt, in de schemering gemakkelijk laat vangen. 


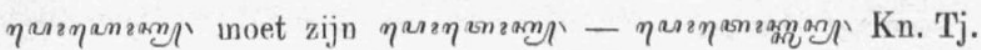

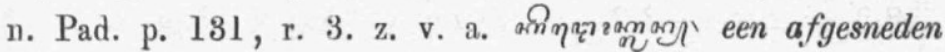

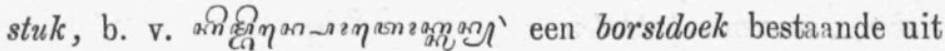

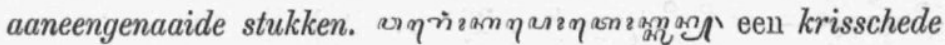
waarvan de eriñzan en de má niet van één stuk hout ge-

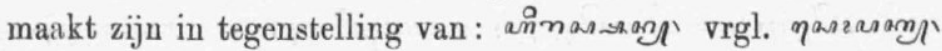

Volgens Mscr. Wbk. "samenvoegen, aan één naaien, samenlasschen van iets waarvan een stuk in het midden ge-

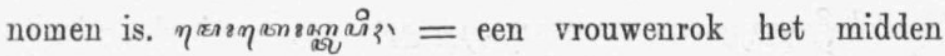
dat versleten is, uitknippen en de beide stukken weder aan een naaien = qая

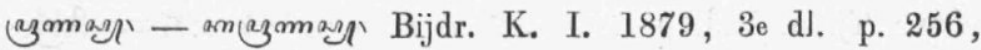

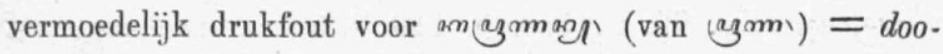
delijk gewond. Uit den samenhang schijnt mij deze lezing beter toe:

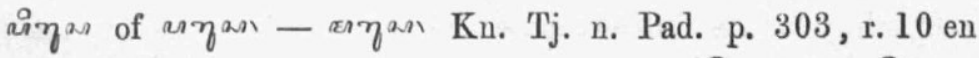

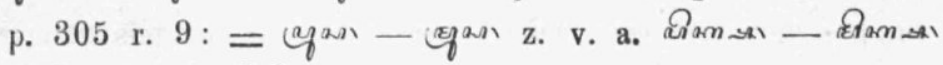

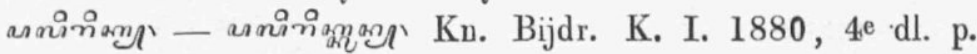
346 , met verdraaide oogen. Dit woord zou m. i. in het Hud. Wbk. gevoegelijk onder het woord nirian kumnen geplaatst worden; maar wanneer men de woorden amaำian en «มำ

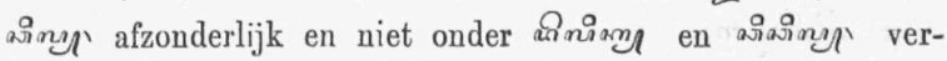
meld vindt, dan zou a nionim $\mathrm{n}$. f. hierop even veel recht hebben.

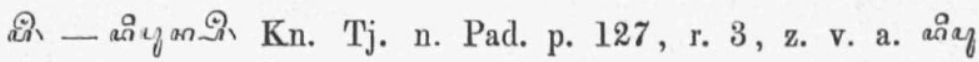

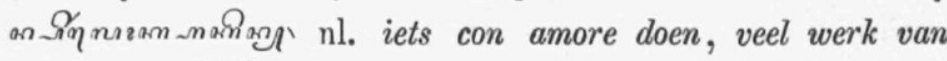
iets maken 요 $z i j n$ beste beentie voorzetten, iets met hart en ziel of zijn uiterste best doen, hoog opvoeren.

as)

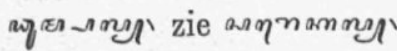

ari

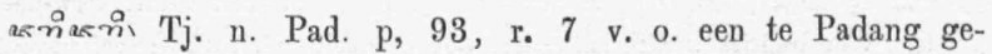
bruikelijk Mal. woord, voor een nagemaakt handje van goud 
of zilver vervaardigd en ten geschenke gegeven aan den anariong houder.

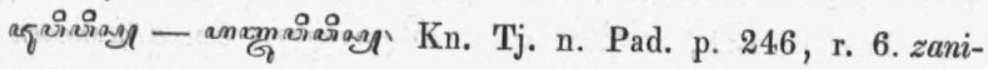

ken, zeuren, babbelen z. v. a. ฌูํำ

ผำๆ ongemanierd staan; loopen en dan weer stilstaan; z. v. a.

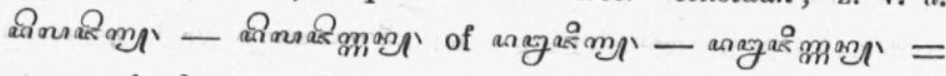
ongemanierd staan of op en neer loopen. Vrgl. ook Bijdr. K. I. 1880,4 e dl. p. 346 .

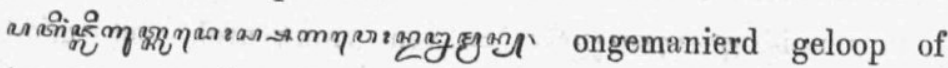
heen en weer loopen, zoo als 's vorsten honden 1. Zie asm ๆoracagyan hierboven.

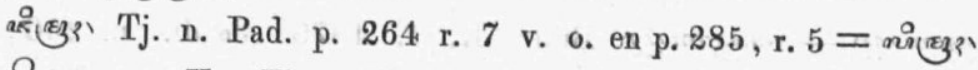
वर्चखुг्था Kn. Tj. n. Pad. p. 116, r. 5 v. o. tusschenw. z. v. a.

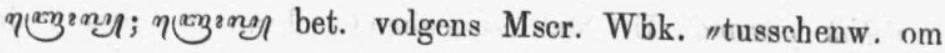
een plotseling uitkomen, het op eens uitschieten uit eene opening aan te duiden, b. v. het ter wereld komen van een kind, het op eens geheel losraken v. d. wortels van een' uitgerukten boom enz."

aำ en kracht; eigenschap van menschen of dieren die met boven-

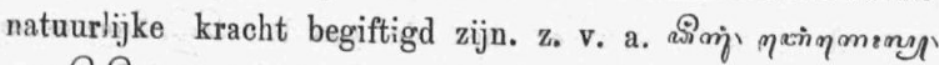
en monny

\section{atm}

x่xนmay Kn. Abiåså p. 39 , r. 7 v. o., keep van een pijl.

(E)

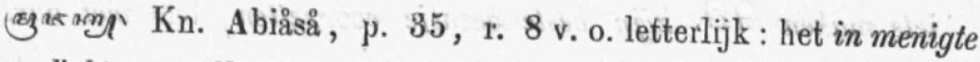
dicht aan elkaar tegelijk uitschieten van lootjes, uitbotten van

1 Wijlen de Sultan VI van Djokja had een honderdtal groote meest overwalsche honden, welke - alleen bij officieële gelegenheden vastgelegd - in de kraton los liepen tot ergernis van sommige vroome inl. ambtenaren, die, neer-

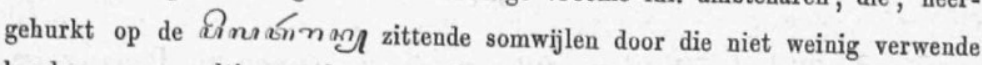
honden, voor paaltjes werden aangezien. Bovenvermelde uitdrukking heeft hoogst waarschijnlijk hieraan haar ontstaan te danken. 
zaden eu plantjes; hier fatsoen van wajangpoppen; 't hoofd

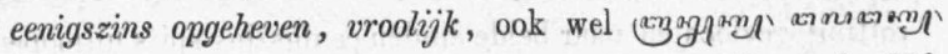

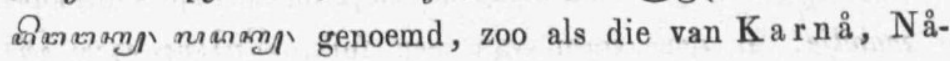

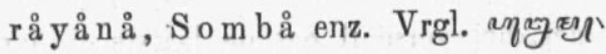

ønamany - gnamån Tj. n. Pad, p. 258, r. 7 z. v. a.

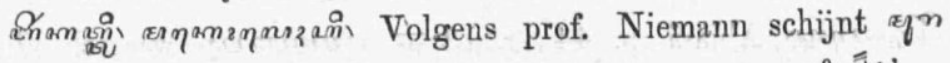

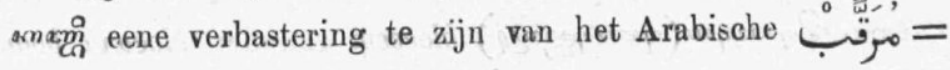
aangeboren; ingeënt (moerakkabboen).

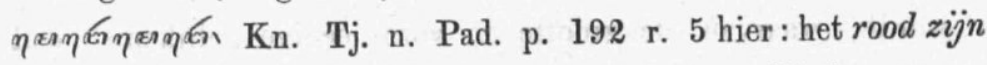

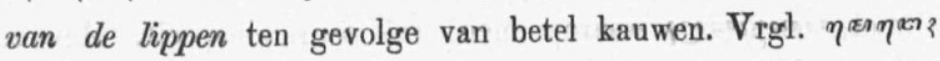

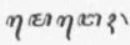

Volgens Mscr. Wbk. "het rood zijn gewoonlijk van de lippen, het zij natuurlijk of van de betel."

$m$ i

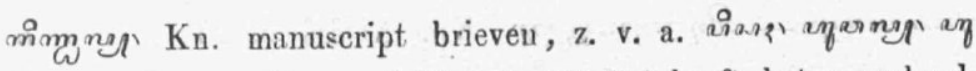
aynar losgeraakt, gescheiden. In Kediri heeft het woord ook de beteekenis van verkoopen.

m緊 Bijdr. K. I. 1880 4e dl. p. 347. Naar mijne bescheiden meening duidt $m \varepsilon_{n}$ hier 10 de daarop volgende zangwijs

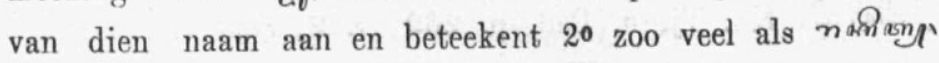
= hecht. vast, waaraan men ook de beteekenis van m m? toekent. Had men hier niet te doen met de volgende zang-

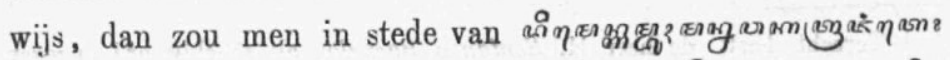

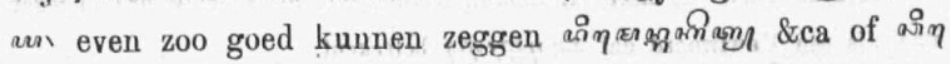

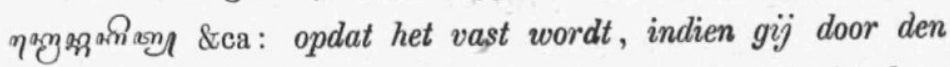
stroom mocht worden overvallen, m. a. w. opdat gij niet door den stroom mede kunt worden gevoerd.

ans

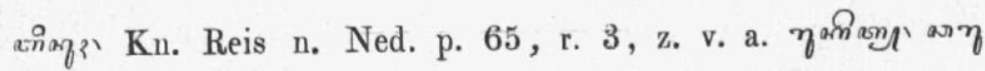

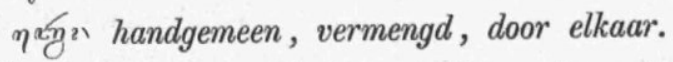

ฉด ஐ̇ Kn. Tj. n. Pad. p. 267 , r. 5 en 6 v. o. en p. 269 , r. 6 v. o. zwaar gebouwd en gehoornd van buffels en run. deren in het algemeen. 


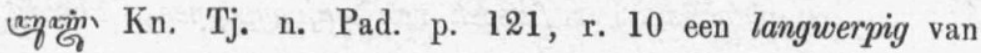
rotting gevlochten naar beide einden eenigszins spits uitloopend

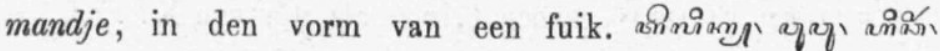

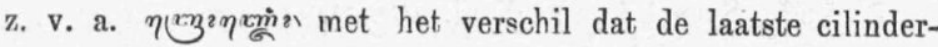
vormig is.

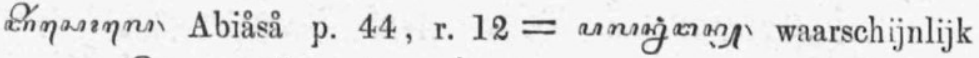

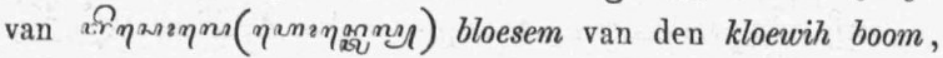
die, gedroogd, wel eens voor de zoogen. "tali api " gebezigd wordt, waarvan de grootte en vorm eenige gelijkenis heeft met arniagicnan waarop men wel eens zinspeelt. Men zegt

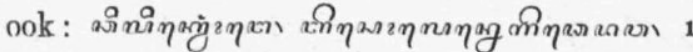

๘дळध $\mathrm{Kn}$. een kleine groene glimmende tor ter grootte van een

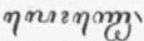

annimion Kn. Tj. n. Pad. p. 307 r. 9 v. o. uitgekleed, dood arm gemaakt zïn, alles verloren hebben, z. v. a. खึंminn

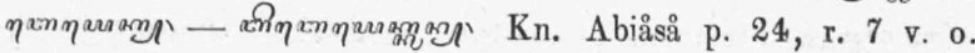

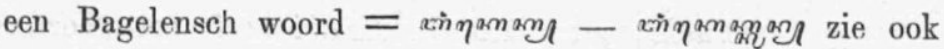

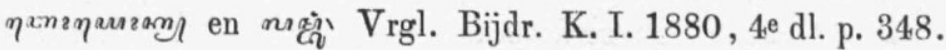

มุा

ตำiำini Kn. Tj. n. Pad. p. 269, r. 2, glad van haren.

Volgens Mscr. Wbk. "doornat v. h. hoofd gezegd, of wanneer het geheele lijf het ook is , maar het lijf alléén niet."

1 Terecht heeft de heer H. Sentanoe Boenglon als scheldwoord opgegeven: ana is een Kawiwoord dat $a \eta \eta m a g n$ beteekent. 